\title{
Hysteria Chemicorum
}

\section{Metabletische beschouwing over een beroepsziekte van scheikundigen ${ }^{1}$}

Hub Zwart

Radboud Universiteit Nijmegen

Faculteit der Natuurwetenschappen, Afdeling Filosofie

"Lieber Freund, Du bist wieder etwas krank, krank an der spezifischen Krankheit der Chemiker, der Hysteria chemicorum, erzeugt durch übermäßige geistige Anstrengung, Ehrgeiz und schlechte Laboratoriumatmosphäre. Alle großen Chemiker leiden daran" (Brief van Friedrich Wöhler aan Justus von Liebig)

Volgens wetenschapssocioloog Robert K. Merton (1973) beleven vooraanstaande fysici en chemici hun finest hour vaak al op zeer jonge leeftijd, gemiddeld tussen het vijfentwintigste en dertigste levensjaar. In de betreffende vakgebieden pieken wetenschappelijke genieën vroeg. ${ }^{2}$ Newton was vierentwintig toen zijn "wonderjaar" aanbrak, Einstein zesentwintig. Na het dertigste levensjaar neemt de productiviteit in de regel snel af. En na hun veertigste hebben exacte wetenschappers als onderzoeker in beginsel afgedaan. ${ }^{3}$ Niet zelden verlaten ze het onderzoek, om manager of bestuurder te worden. Bij biologen vindt dit hoogtepunt enkele jaren later plaats. Ze hebben meer tijd nodig om empirie te vergaren en ervaring op te doen. Alfawetenschappers daarentegen, aan het andere uiteinde van het spectrum, zijn niet zelden laatbloeiers. Vooral geschiedenis is "an old man's game", aldus Merton. ${ }^{4}$ Historici van naam en faam leveren vaak als zestiger of zeventiger nog belangrijke teksten af. Anders gezegd, de typische biografische curve van grote natuurwetenschappers kent een geheel eigen verloop. Kenmerkend is de spectaculaire start, en het verval zet vroegtijdig in. Op latere leeftijd maken ze zich vooral verdienstelijk door handboeken te schrijven, publieksvoordrachten te verzorgen of bestuurlijke functies uit te oefenen.

Dit opmerkelijke sociologische gegeven wil ik in dit artikel aan een "metabletische" beschouwing onderwerpen. Geldt dit fenomeen voor alle tijden, of heeft het veeleer te maken heeft met een bepaalde stijl van wetenschapsbeoefening? Metabletica ("leer van de veranderingen") is de naam die Jan Hendrik van den Berg gaf aan zijn pogingen om wetenschappelijke ontwikkelingen in een bredere

\footnotetext{
${ }^{1}$ Dit artikel is gebaseerd op een voordracht gehouden op 24 oktober 2004 in het Museum Dr. Guislain (Gent), in het kader van een symposium ter gelegenheid van de negentigste verjaardag van J.H. van den Berg.

2 "Creative work peaks early in a scientist's life and diminishes more or less rapidly both in extent and consequence" (Merton 1973, p. 511).

3 "Age is, of course, a fever chill / That every physicist must fear / He's better dead than living still / When once he's past his thirtieth year". Dit gedicht is van de hand van Paul Dirac (1902-1984), Nobelprijswinnaar fysica 1933 (geciteerd in Merton 1973, p. 513).

${ }^{4}$ Dit citaat is ontleend aan I, Claudius van Robert Graves (geciteerd in: Merton 1973, p. 513).
} 
culturele context te plaatsen. ${ }^{5}$ Zoals de titel aangeeft zal ik mij in dit artikel vooral op de levensloop van scheikundigen concentreren. Bij hen krijgt de zojuist geschetste biografische curve namelijk een geheel eigen accent - althans gedurende een bepaalde historische periode, tijdens de pionierstijd van het vakgebied (de achttiende en negentiende eeuw). De nadruk zal in dit artikel overigens niet zozeer op de vroege bloei liggen, noch op de latere periode van recessie, maar veeleer op het moment van crisis, het moment van overgang. Omstreeks het dertigste levensjaar tekent zich in de levensloop van befaamde chemici uit de achttiende en de negentiende eeuw een mid-life crisis af. Na hun herstel bereiken ze zelden nog de helderheid van geest, de productiviteit en creativiteit die ze als twintiger ten toon spreidden. Ik zal betogen dat deze crisis meer behelst dan een sociologisch of fysiologisch gegeven, en dat het evenmin een historische constante is. Het betreft een "metabletisch" fenomeen, een metabletisch ziektebeeld. Dat wil zeggen, het is een symptoom van de werkwijze van de betrokkenen, van de wijze waarop de natuur zich aan hen openbaart, van de wijze waarop zij de werkelijkheid tegemoet treden.

De mid-life crisis die vooraanstaande scheikundigen rond hun dertigste doormaken, wordt in dit artikel als hysteria chemicorum aangeduid. Deze aanduiding wordt voor het eerst gebezigd door Friedrich Wöhler (1800 - 1882) in een brief aan zijn vriend en vakgenoot Justus von Liebig (1803 - 1873), grondlegger van de organische chemie, die juist op dat moment door deze eigenaardige beroepsziekte is getroffen. De term wordt later overgenomen door Wilhelm Ostwald (1853 - 1932), grondlegger van de fysische chemie, die (op latere leeftijd, in 1909) het boek Grosse Männer publiceert, een vergelijkend onderzoek naar biografieën van vooraanstaande scheikundigen in de negentiende eeuw. Hij stelt vast dat in feite alle chemici van naam (althans gedurende de door hem onderzochte periode) aan deze ziekte lijden. Ik begin mijn onderzoek naar de metabletische betekenis van hysteria chemicorum echter bij de proto-pionier van de moderne scheikunde, namelijk Faust.

\section{Faustische wetenschap}

Doctor Faustus, de vroegmoderne wetenschapper aan wie Goethe zijn tragedie wijdde, was een alchemist, een tijdgenoot van Paracelsus. Aan het begin van het toneelstuk treffen we Faust in zijn studeerkamer aan. Hij maakt op dat moment een ernstige mid-life crisis door. Hij heeft zich alle laatmiddeleeuwse disciplines eigen gemaakt, maar moet (als hij eerlijk is) toegeven dat hij eigenlijk niets weet. Dode boekenkennis is steriel en verschaft geen inzicht in de levende werkelijkheid buiten zijn donkere studeercel.

Habe nun, ach! Philosophie,

Juristerei und Medizin,

Und leider auch Theologie

Durchaus studiert, mit heißem Bemühn.

Da steh ich nun, ich armer Tor!

\footnotetext{
${ }^{5}$ Enkele metabletische studies van zijn hand zijn Metabletica of leer der veranderingen [1959], Het menselijk lichaam [1959/1961], Leven in meervoud [1963] en Metabletica van de materie [1968].
} 
Und bin so klug als wie zuvor;

Heiße Magister, heiße Doktor gar...

Und sehe, daß wir nichts wissen können!

Weh! Steck ich in dem Kerker noch?

Verfluchtes dumpfes Mauerloch,

Wo selbst das libe Himmelslicht

Trüb durch gemalte Scheiben bricht!

Beschränkt mit diesem Bücherhauf.... Etc.

Wanneer zijn medewerker Wagner hem tot een wandeling weet te bewegen, blijkt pas hoe ernstig Faust er aan toe is, hoe depressief hij is. Het verhaal is bekend. Hij besluit uiteindelijk zijn studeercel te verlaten en een verbond met de duivel te sluiten. Met andere woorden, wie werkelijk kennis wil vergaren, dient bereid te zijn zeer grote risico's te accepteren - dat is de bij uitstek faustische moraal van het verhaal.

Deze faustische beslissing, deze faustische bereidheid risico's te nemen, ligt ten grondslag aan de moderne wetenschapsbeoefening in het algemeen, maar aan de moderne scheikunde in het bijzonder. Oswald Spengler (1918/1923) duidt deze moderne wetenschappelijke stijl nadrukkelijk als faustisch aan. Het gaat om een extreem ambitieuze en in wezen zelfs gewelddadige vorm van onderzoek die vooral voor de betrokken onderzoeker zelf bijzonder gevaarlijk kan zijn. Faust is als het ware het literaire equivalent van de legendarische monnik Bertold Schwarz die in zijn gotische kloostercel het "duivelse" buskruid ontdekte, en daarbij de dood vond. Faust is het prototype van de faustische wetenschapper die bereid is geweld te gebruiken om een doorbraak te forceren. Hij is echter in de eerste plaats een literaire gestalte. De echte faustische held bij uitstek, die deze denkstijl als geen ander exemplificeerde, is Isaac Newton (1642 - 1727).

\section{Newton: wonderjaar en crisis}

Tijdens zijn "wonderjaar" (1666) sloot Newton zich op in een donkere, lichtdichte ruimte om aldaar, met behulp van een prisma, het fenomeen licht te bestuderen. Aan deze paradoxale beslissing lag een faustische gedachtegang ten grondslag. Door een gaatje in de wand liet hij een minimum aan licht naar binnen vallen dat hij, als faustische onderzoeker, maximaal kon manipuleren en controleren. Faustische wetenschap, aldus Spengler, is wil tot macht. Newton wilde het fenomeen letterlijk in zijn greep krijgen. En en passant ontwikkelde hij de krachtige mathematische instrumenten die hij nodig had om deze faustische machtsgreep mogelijk te maken. Newton was een faustisch genie. Hij was, zoals zijn biograaf Westfall (1980) het treffend uitdrukte, chronisch rusteloos - Never at rest. Hij was bovendien een wetenschapper die zijn omgeving, zijn vakgenoten, op afstand wist te zetten, op afstand wist te houden. Hij was, meer dan wie ook, een man op afstand. Westfall zegt het in zijn inleiding als volgt: 
"The more I have studied him, the more Newton has receded from me. It has been my privilege at various times to know a number of brilliant men, men whom I acknowledge without hesitation to be my intellectual superiors. I have never, however, met one against whom I was unwilling to measure myself, so that it seemed reasonable to say that I was half as able as the person in question, or a third or a fourth, but in every case a finite fraction. The end result of my study of Newton has served to convince me that with him there is no measure. He has become for me wholly other, one of the tiny handful of supreme geniuses who have shaped the categories of the human intellect..." (ix)

Wanneer we ons niet te zeer laten imponeren door bewoordingen die vooral bedoeld zijn om de genialiteit van Newton te benadrukken, en dit soort passages wat "klinischer" lezen, valt op dat de afstand waarover Westfall spreekt met het klimmen der jaren steeds groter wordt. In de loop van zijn leven gaat Newton zich steeds eigenaardiger gedragen. Hij wordt vooral steeds achterdochtiger - "An unpleasant paranoia pervaded his correspondence", geeft Westfall toe. Daarnaast noemt hij nog twee andere eigenschappen die typerend zijn voor Newtons persoonlijkheid. In de eerste plaats zijn bereidheid zichzelf aan enorme persoonlijke risico's bloot te stellen en in de tweede plaats het feit dat zich in zijn biografie momenten van ernstige crisis aftekenen.

Om met het laatste te beginnen: in de levensloop van Newton komen zeer onproductieve en steriele jaren voor, naast perioden van extreme productiviteit en creativiteit (zoals het "wonderjaar"). Er zijn momenten waarop hij ten prooi lijkt te vallen aan epistemologische blokkades, waarin een vreemde intellectuele verlamming zich van hem meester lijkt te maken. Westfall brengt dit in verband met de wijze waarop hij onderzoek verrichtte, met de risico's waaraan hij zichzelf als onderzoeker blootstelde, vooral waar het zijn onderzoek op scheikundig gebeid betrof. Want Newton verrichtte niet alleen onderzoek op het gebied van wiskunde, optica en zwaartekracht, hij was ook jarenlang uitermate actief als chemicus en alchemist. Westfall schrijft:

"One of the tests that Newton commonly applied to his chemicals was taste... He did not hesitate to taste a considerable spectrum of chemicals, many of which contained heavy metals and other toxic substances. He also vaporized a number of dangerous substances in the cramped quarters of his laboratory. Recently, samples of Newton's hair have been tested by the latest techniques for their content of heavy metals and other chemicals... For virtually every element tested, his hair showed concentrations several times those of average hair... Newton nearly poisoned himself".

Newton vergiftigde zichzelf. Gedreven door zijn faustische wil tot weten stelde hij zijn lichaam aan chronische beschadigingen bloot. Daarin stond hij echter niet alleen, integendeel. Hij deelde deze werkwijze met andere chemici, zoals Karl Scheele.

\section{Newtons volgelingen}


De Zweedse chemicus Karl Scheele (1742-1786) ging op dezelfde wijze te werk als Newton. Hij determineerde chemische substanties door eraan te proeven en te ruiken. En ook hij betaalde daarvoor de prijs. Ook hij vergiftigde zichzelf. Paul Strathern (2000) schrijft:

"Scheele suffered from excruciating rheumatism and a series of other ailments. These were almost certainly brought on by his laboratory practices. Scheele was a firm believer in analyzing first-hand the properties of the many substances he isolated and discovered. His laboratory notes even include an accurate description of the taste of hydrogen cyanide, which is extremely toxic and can cause a hideous and painful death... They also show that he could also have poisoned himself identifying by taste and smell the properties of hydrogen sulphide" (p. 195).

Een belangrijke ontdekking van Scheele was bijvoorbeeld het effect van licht op zilververbindingen. Daarmee legde hij in feite de grondslag voor de moderne fotografie. Ook voor deze ontdekking werd echter een hoge prijs betaald, hij boette er zijn gezondheid bij in. ${ }^{6}$

De faustische onderzoekspraktijk die we bij Newton en Schelle aantreffen, vindt in de negentiende eeuw ruimschoots navolging. In deze periode treffen we een groot aantal scheikundigen met chronische gezondheidsklachten aan, klachten die zich doorgaans omstreeks het dertigste levensjaar voor het eerst manifesteren. Wilhelm Ostwald, die zelf in 1909 de Nobelprijs voor de scheikunde won, is zich op latere leeftijd met de geschiedenis van zijn vakgebied gaan bezighouden. Dit resulteerde in de studie Grosse Männer uit 1909 die ik zojuist al noemde. In dit boek worden de lotgevallen beschreven van Humphry Davy (1778-1829), Michael Faraday (1791-1867), Julius Robert Mayer (1814-1878), Charles Gerhardt (1816-1856), Justus von Liebig (1803-1873) en Hermann Helmholtz (1821-1894). Al deze levensverhalen nemen in feite de vorm van ziektegeschiedenissen aan.

\section{Grote, zieke mannen}

Wanneer de beroemde scheikundige Justus von Liebig veertig jaar oud is, is hij dodelijk vermoeid en uitgeblust. Zijn goede vriend Friedrich Wöhler, die als eerste een organische stof (ureum) via synthese in een laboratorium wist te vervaardigen, spreekt hem in een brief bemoedigend toe:

"Lieber Freund, Du bist wieder etwas krank, krank an der spezifischen Krankheit der Chemiker, der Hysteria chemicorum, erzeugt durch übermäßige geistige Anstrengung, Ehrgeiz und schlechte Laboratoriumatmosphäre. Alle großen Chemiker leiden daran" (Ostwald, p. 180).

Collega Berzelius reageert ongeveer in dezelfde bewoordingen. Ook hij lijdt, schrijft hij, aan "hypochondrie". Ook hij ervaart het leven als buitengewoon troosteloos: "Auch selbst bin ich immer krank... Das Laboratorium ist mir ekel" (p. 180).

\footnotetext{
6 "Scheele also discovered the effect light has on compounds containing silver... But [his] first-hand involvement in chemical analysis eventually took its toll" (Strathern 2000, p. 198).
} 
Das Laboratorium ist mir ekel... Dat is niet gering als we bedenken dat het laboratorium voor een scheikundige zal zijn wat een studeerkamer voor een geesteswetenschapper is. In deze verzuchting klinkt een echo door, zo lijkt het, van problematiek, de melancholie van Faust. Een andere befaamde chemicus uit diezelfde periode, Charles Gerhardt, lijdt al aan hysteria chemicorum wanneer hij nog geen dertig is: "Mir widersteht jetzt oft das Laboratorium". Op zijn veertigste sterft hij.

Ziekte, aldus Ostwald, die ook zelf met chronische gezondheidsklachten kampte, lijkt een tyische, onvermijdelijke gebeurtenis te zijn in het leven van het natuurwetenschappelijke genie. Wat is de herkomst van deze vreemde ziekte die vooraanstaande scheikundigen, tot diep in de negentiende eeuw, telkens weer overvalt? Laten we de lotgevallen van deze zieke mannen, wier biografieën door Ostwald aan een vergelijkend onderzoek worden onderwerpen, wat nader bestuderen.

De biografie van Humphry Davy staat als het ware het model voor de chemici die na hem komen. De grote daden worden betrekkelijk vroeg verricht, nog voor het dertigste levensjaar. Dan volgt een crisis, een ernstige ziekte. $\mathrm{Na}$ een periode van extreme productiviteit zet de onvermijdelijke neergang in. De oorzaak moet volgens Ostwald worden gezocht in overbelasting, "Überanstrengung des Organismus". Wetenschap is een zaak van langdurige, extreem geconcentreerde arbeid, vaak onder ongustige condities (in een koude, vochtige, vervuilde laboratoriumomgeving), met alle gevolgen van dien voor het "organisme" van de onderzoeker. Na de crisis is de competentie significant afgenomen. Er heeft zich een verandering voltrokken die niet meer kan worden goedgemaakt. De onderzoeker wordt nooit meer dezelfde als voorheen. Hij bereikt nooit meer het niveau van voor de crisis. En hij wordt, onvermijdelijk, voorbij gestreefd. Davy wordt voorbij gestreefd door zijn leerling Michael Faraday, maar ook diens levensverhaal laat zich lezen als een ziektegeschiedenis met een (voor chemici) typische structuur.

In de periode 1836/1837 maakt Faraday een ernstige gezondheidscrisis door. Dat de crisis zich in zijn geval betrekkelijk laat manifesteert, heeft misschien te maken met zijn gedisciplineerde leefstijl en de bijzonder zorgvuldige, systematische werkwijze die hij zich eigen had gemaakt, maar de ernst van de crisis is er niet minder om. Chronische uitputting en afname van productiviteit zijn de bekende, om niet te zeggen typische klachten. Pas in 1845 is hij voldoende hersteld om zijn onderzoek weer voort te zetten, maar zijn gezondheid blijt hem voortaan parten spelen. Met name wordt hij geplaagd door ernstige geheugenproblemen. "Mein Gedächtnis ist verschwunden", verzucht hij in een van zijn brieven, "Ich bin ein alter Arbeiter, fühle, daß ich verbraucht bin". Op een gegeven moment is zijn geheugen zo zwak geworden dat hij proeven gaat doen die hij al eerder uitvoerde, zonder dat hij zich dat kan herinneren. Hij maakt nauwgezet notities omdat hij vreest dat hij anders alles zal vergeten. Hij krijgt steeds meer last van concentratieproblemen. En terwijl hij in zijn jonge jaren veel zorg besteedde aan orthografie, gaat hij steeds meer schrijffouten maken.

De meest dramatische ziektegeschiedenis in de reeks is echter die van Julius Robert Mayer. Hij was een arts die in zijn vrije tijd natuurwetenschap beoefende en uiteindelijk naam maakte als ontdekker 
van de eerste hoofdwet van de thermodynamica, de Wet van Behoud van Energie. Hij was overigens autodidact, onderwijs in de natuurkunde had hij nooit gehad. De gedachte dat energie zich in uiteenlopende vormen manifesteert en derhalve nooit verloren gaat, maar wel voortdurend van karakter verandert ("transmuteert" als het ware), maakte zich van hem meester toen hij zich als zesentwintigjarige arts had laten inschepen naar Nederlands Indië. Aan boord vertelde een ervaren zeeman hem dat zeewater na een zware storm opvallend warm is, en deze opmerking zette hem aan het denken. Het kritische ogenblik volgde kort na de landing, op de rede van Surabaya waar hij, aldus Wilhelm Ostwald (1909), met geweld werd overvallen door de gedachte die zijn leven zou veranderen. Het was als een bekeringservaring, die in hevigheid niet onderdeed voor die van Paulus. De gedachte doemde plotseling op, maakte zich van hem meester. Het was een intellectuele roeservaring, een moment van inspiratie en inzicht, dat heftige gevoelens opriep en hem nooit meer los zou laten. Sterker nog, de gedachte zou hem noodlottig worden. Ze werd een obsessie. En erkenning zou lang op zich laten wachten.

Thuis gekomen zette hij zich ertoe de gedachte nader uit te werken en te onderbouwen. Hij stelde bijvoorbeeld vast dat wanneer we een fles met water vullen en de fles goed schudden, de temperatuur van het water toeneemt. In feite betreft het een gewone, algemeen bekende ervaring. Wanneer we bij strenge vorst in onze handen wrijven, maken we gebruik van de wet van behoud van energie. Beweging wordt omgezet in warmte. Nadat een eerder manuscript was afgewezen verschijnt in 1842 zijn klassieke publicatie - maar niemand neemt er nota van. De jaren verstrijken en langzaam maar zeker begint Mayer zich zorgen te maken. Intussen stoort zijn echtgenote zich in toenemende mate aan het feit dat hij alleen nog voor zijn gedachte lijkt te leven. Hij blijft echter hardnekkig volhouden dat hij een belangrijke ontdekking heeft gedaan. In 1850 springt hij tijdens een slapeloze nacht uit het raam en raakt daarbij ernstig gewond. Onder dwang wordt hij opgenomen in een psychiatrische inrichting. Daar weigert hij toe te geven dat het verhaal van zijn belangrijke ontdekking op grootheidswaanzin berust. En na ontslag weigert hij zichzelf gezond te verklaren, - hij is immers nooit ziek geweest - hetgeen hem ernstig in de uitoefening van zijn beroep als arts belemmert. Hij verdwijnt uit de openbaarheid, zijn publikaties worden niet gelezen. Er verschijnt zelfs een mededeling in een tijdschrift dat hij zou zijn overleden. Het was zijn lot, aldus Ostwald, ontvankelijk te zijn voor een fundamentele gedachte, - een van de belangrijkste gedachten van de negentiende eeuw -, die de ontdekker zelf voornamelijk ellende zou bezorgen. Zijn levensverhaal is kortom een zeer dramatische illustratie van het basale schema: een belangrijke ontdekking op jonge leeftijd, gevolgd door een crisis en een lange periode van fysieke en mentale ellende.

In het geval van Mayer zouden we er nog op kunnen wijzen dat hij wellicht niet over een robuste persoonlijkheidsstructuur beschikte, dat hij in termen van psychologische aanleg extreem kwetsbaar was. Dat lag beslist anders in het geval van Justus von Liebig. Hij was een stabiele, actieve, krachtige persoonlijkheid, niet alleen een groot onderzoeker, maar ook productief als auteur en een begaafd organisator. In tegenstelling tot de introverte Mayer was hij met nadruk extravert en communicatief. Toch tekent zich ook in zijn loopbaan het inmiddels bekende scenario af. 
Al op eenentwintigjarige leeftijd wordt Liebig benoemd tot hoogleraar aan de universiteit van Giessen. Als onderzoeker is hij buitengewoon actief en effectief. "Wir arbeiteten, wenn der Tag begann, bis zur sinkenden Nacht; Zerstreuungen und Vergnügungen gab es in Gießen nicht" (Ostwald, p. 168). In feite is hij de grondlegger van de organische chemie. Maar hij maakt ook naam als organisator. Hij introduceert het scheikundige practicum. Dat wil zeggen, hij richt een modern laboratorium in zodat studenten naast theoretische inzichten ook praktische vaardigheden kunnen verwerven. $\mathrm{Na}$ zijn dertigste echter beginnen chronische vermoeidheidsverschijnselen hem parten te spelen. Als hij veertig is, heeft hij zijn gezondheid grondig ondermijnd. Wöhler en Berzelius schrijven hem dan de troostende regels die ik hierboven al citeerde. Liebig herstelt weliswaar, maar de tweede levensfase ziet er heel anders uit dan de eerste. Hij trekt zich goeddeels terug uit het laboratorium en wordt, in de eerste plaats, auteur. Het accent komt te liggen op "schriftstellerische Tätigkeit", schrijft Ostwald. Met name gaat hij de Annalen der Chemie redigeren, een vooraanstaand tijdschrift dat nog steeds bestaat. En waar het zijn activiteiten als onderzoeksmanager betreft verschuift de aandacht van fundamenteelwetenschappelijk naar toegepast onderzoek. Dit resulteert onder meer in de eerste bouillon-blok, het Justus von Liebig Fleisch Extrakt. Ook zijn vriend Berzelius staakt na de crisis-fase het experimenteren en gaat schrijven. Een afkeer van het lab maakt het hen onmogelijk hun laboratoriumarbeid te continueren. Hun conditie, hun fysiologie is aangetast. Liebig blijft weliswaar actief, zoals gezegd, maar beklaagt zich regelmatig over uitputting en "allgemeines Mißbefinden". Hij onderschrijft de diagnose van Wöhler, al spreekt hij in plaats van Hysteria liever over Neurasthenia Chemicorum.

Ook Hermann Helmholtz ten slotte, de laatste grote scheikundige die Ostwald bespreekt, gaat gebukt onder ernstige chronische kwalen, al betreft het in zijn geval vooral migraine. Ostwald concludeert uiteindelijk dat grote wetenschappers op latere leeftijd vaak "invalide" worden. Ze hebben hun gezondheid en vitaliteit aan de wetenschap opgeofferd. Wat hen in de tweede levenshelft nog rest zijn treurige invaliditeitsjaren. Het zijn Invaliden der Wissenschaft geworden. Na hun grote productieve daad, die ze vaak al op jonge leeftijd verrichtten, zijn ze tot steriliteit veroordeeld. Wie een significante bijdrage aan de natuurwetenschappen heeft geleverd, aldus Ostwald, zou gedurende de rest van zijn leven met rust gelaten zou moeten worden.

\section{Een natuurwetenschappelijke en een metabletische verklaring}

De verleiding is groot om, voor een probleem dat eerst en vooral natuurwetenschappers treft, een natuurwetenschappelijke verklaring te zoeken. Deze verklaring leek zich aan te dienen toen de Duitse chemicus Alftred Stock (1876 - 1946) in 1926 een artikel publiceerde waarin om te beginnen duidelijk wordt gemaakt dat de beroepsziekte der chemici op dat moment nog zeker niet tot het verleden behoorde. Hij beschrijft, op zeer herkenbare wijze, de chronische symptomen waaraan ook eerdere generaties chemici blootstonden. Op vijftigjarige leeftijd, terugblikken op zijn loopbaan, bekent hij, in een opvallend persoonlijke en openhartige beschouwing, dat hij al bijna vijfentwintig jaar te maken heeft gehad met lusteloosheid, rusteloosheid, vermoeidheid en geheugenproblemen. Het is de moeite 
waard om dit document, op de grens van chemie en auto-biografie, wat nauwkeuriger te bekijken, hardop te lezen als het ware, aan een "lecture à haute voix" te onderwerpen.

In zijn artikel, dat destijds veel opzien baarde, wil Stock vooral waarschuwen tegen de schadelijke gevolgen van blootstelling aan kwik (Quecksilber) tijdens laboratoriumwerkzaamheden:

"Wenn ich mich entschliesse, einem weiteren Kreise rückhaltlos über persönliches Ungemach zu berichten ... so treibt mich dabei der heisse Wunsch, alle, die mit metallischem Quecksilber zu tun haben, aufs eindringlichste vor den Gefahren des flüchtigen Metalles zu warnen und ihnen die schlimmen Erfahrungen zu ersparen, die mir einen grossen Teil meines Leben verdorben haben" (1926a, p. 461).

Zijn symptomen omschrijft hij als volgt:

"Seit beinahe 25 Jahren litt ich an Beschwerden, die, anfangs schwach und nur gelegentlich auftretend, allmählich mehr und mehr, schliesslich fast bis zur Unerträglichkeit zunahmen, so dass ich schon daran verzweifelte, weiter wissenschaftlich arbeiten zu können" (p. 461)

Stock noemt als klachten: zware chronische hoofdpijn, "erethisme" (extreme prikkelbaarheid), nerveuse onrust, problemen met luchtwegen en ademhaling, matheid en lustloosheid ("unfähigkeit zu jeder, besonders geistiger Arbeit"), depressiviteit, tandvleesproblemen, caries, en geheugenproblemen ("Minderung des Gedächtnisses"). De ernst van de klachten neemt geleidelijk toe. Over zijn geheugenproblemen schrijft hij bijvoorbeeld:

"Mein ursprünglich ausgezeichnetes Gedächtnis liess mehr und mehr zu wünschen übrich und wurde immer schlechter, so dass ich vor zwei Jahren völliger Gedächtnislosigkeit nahe war. Nur mit Hilfe umfangreicher Aufzeichnungen konnte ich mit grösster Anstrengung eine Abhandlung verfassen oder einen Vortrag halten" (p. 461)

Hij vergeet namen en telefoonnummers en ook zijn rekenvaardigheid neemt af. Met schrijven gaat hij steeds meer spelfouten maken. Vakanties helpen niet. Langzaam maar zeker wordt wetenschappelijke arbeid zo goed als onmogelijk.

Dit is hysteria (of neurasthenia) chemicorum ten voeten uit. En Stock was zich daar ook van bewust. Hij kende de ziektegeschiedenis van Faraday en vraag zich af hoeveel meer deze grote chemicus voor de wetenschap had kunnen betekenen wanneer hij niet aan kwikvergiftiging ten prooi was gevallen. Ook de langdurige ziekte waarmee Blaise Pascal al op jonge leeftijd sukkelde, wordt toegeschreven aan diens experimenten met kwikbarometers. Hij werd in feite door zelfde symptomen gekweld. 
Wanneer zijn klachten zich manifesteren zoekt Stock aanvankelijk naar somatische oorzaken. Hij wordt aan een reeks operaties, met name neusoperaties onderworpen, maar zonder resultaat. Wanneer zijn medewerkers dezelfde klachten gaan vertonen, gaat hij een verband leggen met het chemisch laboratorium als omgeving. Een bevriende toxicoloog stelt uiteindelijk de oorzaak vast: kwikvergiftiging. Er worden drastische maatregelen genomen om de arbeidsomstandigheden in het laboratorium te verbeteren, maar het herstel verloopt uiterst traag. In feite is het alleen jonge medewerkers nog gegeven hun oorspronkelijke niveau van mentale helderheid opnieuw te bereiken. Naar aanleiding van zijn artikel ontvangt Stock veel brieven van collega's die vergelijkbare gezondheidsklachten rapporteren. Tientallen chemici blijken aan het ziektebeeld te lijden.

Terloops maakt Stock in zijn artikel ook melding van de risico's van kwikhoudende substanties die tandheelkundigen gebruiken voor vullingen. Caries is een gevolg van hysteria chemicorum, en de behandeling ervan met kwikhoudende vullingen maakt het probleem alleen maar erger. In een vervolgartikel (1926b) gaat hij nader op deze kwestie in. In de eerste plaats houdt het gebruik van deze materialen een risico in voor tandartsen zelf die met amalgaam-vullingen werken, aldus Stock. Dit verklaart volgens hem de in zijn ogen opvallend hoge incidentie van nervositeit in deze beroepsgroep. Maar ook de dragers van amalgaam-vullingen lopen evidente risico's. Ook zij kunnen neurasthenische symptomen gaan vertonen. Hij beschikt echter niet over voldoende documentatie, schrijft hij, om dit nader te onderzoeken. Stock was in zijn tijd een gezaghebbende wetenschapper en zijn artikelen roepen een heftige debat op over het gebruik van kwikhoudende materialen voor amalgaam-vullingen in de tandartspraktijk - een debat dat spoedig ook in kranten en andere publieke media wordt gevoerd. De tandartsen gaan in de verdediging. Bij miljoenen patienten zijn amalgaamvullingen ingebracht, zonder dat ze de door Stock beschreven klachten vertonen. Stock besluit daarop van de polemiek met de tandheelkundigen zijn levenswerk te maken (Breenkoetter 1984). In de jaren die volgen publiceert hij ongeveer vijftig artikelen over kwikvergiftiging en de rol van tandheelkunde daarbij.

In de negentiende eeuw namen Amerikaanse tandartsen bij de introductie van amalgaam het voortouw, aldus Breenkoetter (1984). Het amalgaam-tijdperk begint in 1833 in New York, waar de gebroeders Crawcour het fenomeen amalgaam-vulling introduceren. Deze techniek stuit echter op verzet bij traditionele tandartsen, die zich met name zorgen maakten over de gevolgen van het gebruik van zware metalen voor de gezondheid van de betrokkenen. Niettemin verbreidt de techniek zich snel en de gebroeders Crawcour zelf weten in korte tijd een fortuin te verwerven. In zijn artikel wijst Breenkoetter er echter op dat in dezelfde periode een vreemde ziekte van zich doet spreken, een psychopathologische epidemie - het zogeheten American Nervosisme, een ziektebeeld dat in 1869 door de New Yorkse neuroloog George M. Beard voor het eerst wordt beschreven. Beard wijdt een groot deel van zijn leven aan de speurtocht naar organische oorzaken voor deze ziekte, maar zonder succes. Kennelijk, aldus Beard, wordt deze vorm van nervositeit veroorzaakt door de Amerikaanse levensstijl, het Amerikaanse levenstempo, dat samenhangt met de introductie van electriciteit, stoomenergie en moderne communicatiemiddelen. Breenkoetter benadrukt, welhaast als een 
metabletische epidemioloog, de gelijktijdigheid van beide ontwikkelingen. De introductie van kwikhoudende vullingen en de opkomst van Amerikaanse nervositeit vallen historisch gezien min of meer samen. Een van de symptomen die Beard noemt in verband met Amerikaanse nervositeit is caries. Breenkoetters stelt dat er weliswaar sprake was van een samenhang tussen caries en nervositeit, maar op een geheel andere wijze dan Beard meende. Door de gevolgen van American Nervosisme met kwikhoudende vullingen te bestrijden, waren Amerikaanse tandartsen in feite mede schuld aan het probleem. Ook American nervosisme was in feite niets anders dan de kwikvergiftiging. Beide ziektebeelden waren in wezen identiek. Bij Amerikaanse burgers hingen de klachten samen met de bestanddelen van vullingen, bij chemici werden de klachten veroorzaakt door blootstelling aan kwik of kwikhoudende substanties in een laboratorium-setting. Newton, Scheele en andere bekende chemici hadden met kwik gewerkt, zonder de benodigde beschermende maatregelen te nemen.

Vanuit metabletisch perspectief is deze verklaring interessant, maar zeker niet afdoende. Hysteria chemicorum laat zich niet tot kwikvergiftiging reduceren, al was het alleen maar omdat kwikvergiftiging zelf weer een symptoom, een "gevolg" is van een meer fundamentele problematiek. Kwikvergiftiging maakt deel uit van een bepaalde stijl van onderzoek en interventie, die zich zowel in de chemie als in de tandheelkunde aftekent. De gelijktijdige aanwezigheid van kwik in het chemische laboratorium en in de tandartspraktijk, halverwege de negentiende eeuw, is een manifestatie van een bepaalde wijze van interacteren met de natuur - met de natuur in het algemeen en met het menselijk lichaam (waartoe uiteraard ook het gebit moet worden gerekend) in het bijzonder.

Hysteria chemicorum maakt deel uit van een tijdperk waarin chemici er op uit waren de materie stap voor stap tot elementen van het periodieke systeem te reduceren. Stoffen als kwik werden als het ware losgemaakt van hun natuurlijke omgeving. In een "onnatuurlijke", kunstmatige laboratoriumcontext werden ze object van systematisch scheikundig onderzoek. Daar kwamen deze "elementen" in extreem grote en (vooral) extreem pure concentraties voor, tegelijk als grondstof en als product, zodat de "zuivere" scheikundige rede haar werk kon doen: reductie van natuurlijke materialen tot elementen uit het periodieke systeem - reductie en recombinatie, analyse en synthese. In het chemische laboratorium, aldus Van den Berg (1963) wordt water bijvoorbeeld tot $\mathrm{H}_{2} \mathrm{O}$ gereduceerd. $\mathrm{Er}$ ontstaat een nieuwe, "zuivere" materie. Stap voor stap wordt in chemische laboratoria oude in nieuwe materie omgezet. Ook het menselijk lichaam wordt, meer dan ooit, aan deze nieuwe materie, aan deze pure, zuivere elementen blootgesteld. Dit geldt voor het lichaam van de onderzoekers zelf, maar evenzeer voor het lichaam van patiënten, bijvoorbeeld van patiënten die kampen met cariës. Grote chemici betaalden de tol voor hun bereidwillige deelname aan dit faustische programma, maar ook tandartspatiënten ondervonden de effecten.

Dit geldt ook voor de samenhang tussen hysteria chemicorum en leeftijd. Dat de in dit artikel beschreven chemici vroeg piekten, terwijl hun prestaties als onderzoeker na hun dertigste steevast afnamen, heeft primair te maken met het feit dat de scheikunde in de negentiende eeuw een laboratoriumwetenschap werd. Chemici trokken zich in laboratoria terug (Bachelard 1938/1949). Het 
laboratorium was een kunstmatige, uitzonderlijke, maar ook buitengewoon ongezonde en gevaarlijke omgeving. Hysteria chemicorum was de prijs die chemici voor hun afzondering betaalden. Wanneer scheikunde een meer beschouwende, meer "theoretische" wetenschap in de eigenlijke zin zou zijn geweest, zou de typische biografische curve van chemici een ander verloop hebben gekend. Dat wil zeggen, we kunnen hysteria chemicorum niet op één oorzaak terugvoeren. Het ziektebeeld maakt deel uit van een complex geheel: de scheikundige onderzoekspraktijk zoals die met name in de negentiende eeuw gestalte kreeg. Via medische en tandheelkundige toepassingen verspreidde het ziektebeeld zich vervolgens, in uiteenlopende gestalten (waaronder American nervosisme), ook buiten het laboratorium. Het menselijk lichaam, eerst van onderzoekers, vervolgens van medici en tandheelkundigen, en tenslotte van patiënten, werd aan typische laboratoriummaterialen blootgesteld, met alle iatrogene gezondheidsproblemen van dien.

Dat het een metabletische problematiek betreft wordt nog benadrukt door het feit dat we haar niet alleen in chemische laboratoria of tandheelkundige praktijken aantreffen, maar ook in een domein dat zich juist kritisch tot dominante kennisvormen wilde verhouden, de alternatieve geneeskunde. Samuel Hahnemann (1755-1843), tijdgenoot van Humphry Davy, geldt als grondlegger van de homeopathie. Zijn onderzoekspraktijk was zo mogelijk nog risicovoller en dramatischer dan die van chemici als Davy of Scheele. Hij was, misschien wel meer dan wie ook, bereid zijn lichaam aan giftige chemische substanties zoals arsenicum bloot te stellen. In zijn recente boek Die Sonne und der Tod schrijft Peter Sloterijk (2001) over hem het volgende: "Er war ein Virtuose der Selbstvergiftigung. Er hat seinen Körper geprüft, getestet, belastet ... in einer Weise, die aus inm eine grosse Orgel der Krankheitszustände gemacht hat".

De slotvraag betreft de actuele betekenis van het in dit artikel beschreven fenomeen. Het hedendaagse chemische laboratorium is grondig van karakter veranderd. Chemici werken zelden nog met arsenicum of kwik. Hedendaagse chemici bevinden zich in de regel achter een computerscherm waar zij, met behulp van geavanceerde computerapplicaties, macromoleculen analyseren en manipuleren. De hedendaagse beroepsziekte van chemici is niet hysteria chemicorum, maar RSI (een afkorting van Computer Related Repetitive Strain Injury)- de epidemie van onze tijd. Deze ziekte is overigens niet specifiek voor chemici, maar komt in vrijwel alle wetenschapsgebieden voor, eenvoudigweg omdat de computer het algemene, universele, discipline-overstijgende onderzoeksinstrument geworden is. Chemici werken zelden nog met pure elementen. Zij onderzoeken bij voorkeur complexe chemische processen en systemen. Het is niet langer hun ambitie de natuur tot "zuivere" grondstoffen te reduceren. Veeleer ontwerpen ze produkten en materialen die op een meer intelligente wijze met de natuur interacteren, die de natuur zelfs zoveel mogelijk willen imiteren (in de vorm van "biomaterialen"). In medische en tandheelkundige praktijken zal dit (nu en in de toekomst) leiden tot het toenemend gebruik van lichaamsvriendelijke materialen en technieken, die zich, meer dan de produkten van de oude scheikunde, zullen voegen naar de natuur. Hysteria chemicorum is bij uitstek een metabletisch ziektebeeld dat uitdooft op het moment dat de scheikunde, evenals de cultuur waarvan dit wetenschapsgebied deel uitmaakt, drastisch van karakter verandert. 


\section{Bibliografie}

Jan Hendrik van den Berg (1963) Leven in meervoud. Een metabletisch onderzoek. Nijkerk:

Callenbach.

Gaston Bachelard (1938/1949) La psychanalyse du feu. Paris: Gallimard.

W. Breenkoetter (1984) Hätte Professor Stock recht? Biologische Medizin, 4, 194-197.

Robert K. Merton (1973) The sociology of science. Theoretical and empirical investigations. Chicago \& London: the University of Chicago Press.

IWilhelm Ostwald (1909) Grosse Männer. Leipzig: Akademische Gesellschaft.

Peter Sloterdijk (2001) Die Sonne und der Tod: Dialogische Untersuchungen. Frankfurt: Suhrkamp Verlag.

Oswald Spengler (1918 / 1923) Der Untergang des Abendlandes. Umrisse einer Morphologie der Weltgeschichte. Erster Band: Gestalt und Wirklichkeit. 33e druk. München: Beck

Alfred Stock (926) Die Gefährlichkeit des Quecksilberdampfes. Zeitschrift fur angewandte Chemie, 39:461-68.

Alfred Stock (1926b) Die Gefährlichkeit des Quecksilberdampfes und der Amalgame. Zeitschrift fur angewandte Chemie, 39. 984-89

Paul Strathern (2000) Mendeleyev's dream. New York: Berkley Books.

Richard S. Westfall (1980) Never at rest. A biography of Isaac Newton. 